\title{
Dexamethasone-induced growth inhibition of porcine growth plate chondrocytes is accompanied by changes in levels of IGF axis components
}

\author{
J J Smink, J A Koedam, J G Koster and S C van Buul-Offers \\ Department of Pediatric Endocrinology, University Medical Center Utrecht, PO Box 85090, NL-3508 AB Utrecht, The Netherlands \\ (Requests for offprints should be addressed to J J Smink; Email: J.Smink@wkz.azu.nl)
}

\begin{abstract}
High (pharmacological) doses of glucocorticoids inhibit the proliferation of growth plate chondrocytes, which leads to one of the side-effects of these steroids, namely suppression of longitudinal growth. Growth inhibition by glucocorticoids is thought to be mediated in part by impaired action of components of the IGF axis, which are important for chondrocyte regulation and hence for longitudinal growth. The aim of the present study was to determine whether glucocorticoid-induced growth retardation involves changes in IGF axis components. Chondrocytes were isolated from epiphyseal growth plates of neonatal piglets and treated with pharmacological doses of dexamethasone (DXM) for $24 \mathrm{~h}$ to study glucocorticoid-induced growth retardation. Under IGF-Isupplemented $(10 \mathrm{nM})$ culture conditions, IGF-binding proteins (IGFBPs)-2, -4 and -5 were secreted by the growth plate chondrocytes and IGFBP-2 protein and mRNA levels were decreased by the DXM treatment, whereas IGFBP-4 and -5 were not affected. Proliferation of the chondrocytes, as measured by $\left[{ }^{3} \mathrm{H}\right]$ thymidine incorporation, was $3 \cdot 5$-fold higher in serum-supplemented medium in contrast to IGF-I-supplemented (10 nM) medium. In the presence of serum, DNA synthesis
\end{abstract}

was significantly inhibited by $50-63 \%$ when treated with $100 \mathrm{nM}$ DXM, which was prevented by the glucocorticoid-receptor antagonist Org34116. mRNA levels of IGF axis components were determined using Northern blot analysis. IGFBP-2 to -6 were expressed in the chondrocytes, IGFBP-1 was absent and both IGF-I and IGF-II, and the type I and type II IGF receptors were expressed. Treatment with DXM $(100 \mathrm{nM})$ resulted in a 2 -fold increase in mRNA levels of both IGFBP-5 and the type I IGF receptor, whereas IGFBP-2 mRNA levels decreased by $55 \%$, in concert with the decrease in protein level observed under IGF-I-supplemented culture conditions. The changes in mRNA levels due to the DXM treatment were prevented by the glucocorticoid receptor antagonist.

Our data show that exposure to pharmacological doses of DXM results in inhibition of proliferation and changes in components of the IGF axis, IGFBP-2 and -5 and the type I IGF receptor, suggesting a role for these components in glucocorticoid-induced growth retardation at the local level of the growth plate.

Journal of Endocrinology (2002) 174, 343-352

\section{Introduction}

Longitudinal bone growth results from the proliferation, differentiation, maturation and eventually apoptosis of chondrocytes within the growth plates of the long bones (Stevens \& Williams 1999). These processes must be correctly coordinated in order to maintain normal growth.

Glucocorticoids (GCs), although effective drugs in the treatment of several diseases, such as asthma, respiratory distress syndrome and rheumatoid arthritis, may induce growth retardation in children as a side-effect (Allen 1996). Studies in experimental animal models have also shown that high levels of GCs have a growth suppressive effect on longitudinal bone growth (Price et al. 1992, Leili \& Scanes 1998, Rooman et al. 1999, Stevens \& Williams
1999). Several in vivo studies showed that GCs act locally to restrain growth, suggesting a local mechanism which is intrinsic to the growth plate (Baron et al. 1992, Silvestrini et al. 2000).

The inhibitory actions of GCs on longitudinal growth are suggested to be due to impaired action of the components of the insulin-like growth factor (IGF) axis (Price et al. 1992, Jux et al. 1998, Klaus et al. 1998). IGF-I and IGF-II are important mediators of longitudinal growth, as shown by in vitro and in vivo experiments (Van Buul-Offers et al. 1988, D’Ercole 1996, Ohlsson et al. 1998). The IGFs are potent mitogenic and differentiationpromoting growth factors (Cohick \& Clemmons 1993). They are produced by multiple tissues, and can act in both an endocrine and autocrine/paracine fashion. IGFs are 
bound to members of high-affinity IGF-binding proteins (IGFBPs), which modulate the IGF availability and bioactivity (Clemmons 1997, Rajaram et al. 1997). They act mainly as autocrine and/or paracrine factors at or close to their sites of synthesis and have different affinities for the IGFs (Jones \& Clemmons 1995). Growth plate chondrocytes produce both IGFs and IGFBPs, which are presumed to be important for chondrocyte regulation and hence for longitudinal growth (Price et al. 1992, Bhaumick 1993, Sunic et al. 1995, Olney \& Mougey 1999). Both IGFs and several IGFBPs are regulated by GCs (Dell et al. 1999), both in vitro, e.g. in fibroblasts (Conover et al. 1995) and in osteoblasts (Okazaki et al. 1994), as well as in vivo, i.e. determined in serum (Price et al. 1992, Miell et al. 1993, Rooman et al. 1999, Ward et al. 1999) and in liver and lung tissue (Price et al. 1992). However, scarce data are available with respect to the regulation of IGFBPs by GCs on growth plate chondrocytes. We have reported that in rabbit costal chondrocytes, IGFBP-5 expression is downregulated and IGFBP-3 expression is induced by dexamethasone (DXM) (Koedam et al. 2000). In rat growth plate chondrocytes, GCs impair growth hormone $(\mathrm{GH})$ induced stimulation of local secretion and paracrine action of IGF-I, which would contribute to GC-induced growth retardation (Jux et al. 1998). However, in patients treated with GCs, serum IGF-I levels are usually not altered, while its bioactivity is (Caufriez \& Copinschi 1986), indicating that the IGFBPs might be the IGF axis components that are involved in GC-induced growth retardation (Price et al. 1992). Since locally produced IGFs are suggested to have an autocrine/paracrine action on growth and GCs act locally to inhibit longitudinal growth, serum levels of IGF axis components provide little insight into the mechanisms by which GCs induce growth retardation (Ward et al. 1999).

The aim of this study was to investigate whether GC-induced growth retardation indeed is related to changes in expression of components of the IGF axis (both IGFs, the IGFBPs and the IGF receptors) in in vitro cultures of chondrocytes isolated from the neonatal porcine growth plate. The obtained data suggest a role for specific components of the IGF axis in the regulation of chondrocyte growth by GCs at a local level.

\section{Materials and Methods}

\section{Materials}

Restriction enzymes, modifying enzymes, Tripure isolation reagent and Agarose Gel DNA extraction kit were purchased from Roche Molecular Biochemicals (Mannheim, Germany). Nylon membranes (Hybond$\mathrm{N}^{+}$, RediPrime Random Primer labeling mixture, $\left[\alpha-{ }^{32} \mathrm{P}\right] \mathrm{dCTP}(10 \mathrm{mCi} / \mathrm{ml}),\left[{ }^{3} \mathrm{H}\right]$ methyl-thymidine $(1 \mathrm{mCi} /$ $\mathrm{ml})$, the Hyperfilm ECL film and the horseradish peroxidase-conjugated secondary antibody were obtained from Amersham Pharmacia Biotech. Collagenase (C-9891) and protease (P-6911) enzymes were purchased from Sigma Chemical Co. Dulbecco's modified Eagle's medium (DMEM), L-glutamine, penicillin, streptomycin, fetal calf serum (FCS) and SuperScript II Reverse Transcriptase were obtained from Life Technologies. The TOPO TA Cloning kit was obtained from Invitrogen. Cell strainers were purchased from Becton Dickinson. Centricon-10 ultrafiltration membranes and PVDF (Immobilon-P) were from Millipore Corp. BioMax MR $\mathrm{X}$-ray films were obtained from Kodak. Supersignal chemiluminescent substrate was purchased from Pierce. Org34116 (a GC receptor (GR) antagonist) was provided by Organon (Oss, The Netherlands). Dexamethasone disodium phosphate (DXM) from Merck Sharp \& Dohme was from our hospital pharmacy.

Recombinant human IGF-I was kindly provided by Eli Lilly \& Co. The human IGFBP-2 antibody (rabbit antibody directed against a peptide sequence from bovine IGFBP-2), the human IGFBP-5 antibody (rabbit antibody directed against a peptide sequence from human IGFBP-5) and the recombinant human IGFBP-2 were purchased from Upstate Biotechnology Inc. (Lake Placid, NY, USA). Recombinant human IGFBP-5 was obtained from GroPep (Adelaide, Australia). Human IGFBP-1 to -6 cDNAs were kindly provided by Dr S Shimasaki (La Jolla, CA, USA) (Han et al. 1996). GAPDH cDNA was a gift from Dr H van Teeffelen (Utrecht, The Netherlands) (Dufourny et al. 1997). Rat type I (Werner et al. 1989) and mouse type II IGF receptor cDNAs (Ludwig et al. 1992) were a gift from Dr J W van Neck (Rotterdam, The Netherlands). Human IGF-I (Jansen et al. 1983) and -II (Jansen et al. 1985) cDNAs were obtained from Dr M Jansen (Utrecht, The Netherlands).

\section{Cell culture}

Epiphyseal growth plate chondrocytes were isolated from the distal and proximal tibial growth plate of neonatal piglets by splitting the growth plate transversally and dissecting the growth plate free under sterile conditions. The growth plates were minced with a scalpel and digested with $1 \mathrm{mg} / \mathrm{ml}$ protease for $30 \mathrm{~min}$ at $37^{\circ} \mathrm{C}$ with constant shaking in DMEM containing $4.5 \mathrm{~g} / 1$ glucose, $4 \mathrm{mM}$ L-glutamine, $100 \mathrm{U} / \mathrm{ml}$ penicillin and $100 \mu \mathrm{g} / \mathrm{ml}$ streptomycin, followed by digestion with $0.5 \mathrm{mg} / \mathrm{ml}$ collagenase for $6 \mathrm{~h}$ at $37^{\circ} \mathrm{C}$ in the same medium supplemented with $10 \%$ FCS. Cells were filtered through a sterile $70 \mu \mathrm{m}$ nylon cell strainer, centrifuged, counted and seeded in $75 \mathrm{~cm}^{2}$ tissue culture flasks. The cells were grown as a monolayer culture at $37^{\circ} \mathrm{C}$ in a $5 \% \mathrm{CO}_{2}$ and humid atmosphere.

The chondrocyte phenotype of the cells was verified by Alcian blue staining for sulfated proteoglycans (Leonard et al. 1991), expression of type II collagen (Cancedda et al. 1995) and cartilage-derived retinoic acid-sensitive protein 
(CD-RAP) (Dietz \& Sandell 1996) by Northern blot analysis (Koedam et al. 2002).

In general, second and third passage cells were used at subconfluency. Cells were cultured in 10\% FCSsupplemented medium. The amount of GCs contributed by $10 \%$ FCS was measured using a chemiluminescent immunoassay on the Nichols Advantage System (San Juan Capistrano, CA, USA) and was less than $1 \mathrm{nM}$. This concentration is negligible compared with the doses applied in our experiments. Proliferation of cells cultured in dextran-coated charcoal-stripped serum was only $20 \%$ of proliferation of cells cultured in 10\% FCS (data not shown). Therefore, no experiments in dextran-coated charcoal-stripped serum were performed. Proliferation of cells in serum-free medium was only $20 \%$ of cells incubated with 10 nM IGF-I. Therefore, no experiments were performed in serum-free medium; instead, $10 \mathrm{nM}$ IGF-I was added to the serum-free medium. In experiments with the GR antagonist (Org34116), cells were preincubated for $1 \mathrm{~h}$ with $10 \mu \mathrm{M}$ of the GR antagonist or an equivalent volume of the solvent (ethanol) and subsequently treated with DXM (still in the presence of the GR antagonist).

Cell viability at the end of the incubations with DXM was determined by the trypan blue exclusion technique.

\section{${ }^{3}$ H]thymidine incorporation}

Cells were grown on 24-well plates and incubated with increasing concentrations of DXM for $24 \mathrm{~h}$, with or without the GR antagonist, as described above and each experiment was conducted in triplicate, both in serumfree conditions supplemented with $10 \mathrm{nM}$ IGF-I/0 $005 \%$ BSA and in 10\% FCS conditions. The rate of chondrocyte proliferation was assessed by incubating the cells in $0.5 \mu \mathrm{Ci} / \mathrm{ml}$ of $\left[{ }^{3} \mathrm{H}\right]$ thymidine for the final $4 \mathrm{~h}$ of incubation. Cells were subsequently washed with PBS to remove unincorporated isotope and the DNA and protein were precipitated with three incubations of $1 \mathrm{ml} 10 \%$ $(\mathrm{w} / \mathrm{v})$ ice-cold trichloroacetic acid for $15 \mathrm{~min}$ at $4{ }^{\circ} \mathrm{C}$ and solubilized by incubation at room temperature with $0.4 \mathrm{M}$ $\mathrm{NaOH}$ for $1 \mathrm{~h}$. Isotope incorporation was measured by liquid scintillation counting.

\section{Western blotting}

Cells were first preincubated with serum-free medium for $2 \mathrm{~h}$, after which medium was changed for medium supplemented with $10 \mathrm{nM}$ IGF-I and 0.005\% BSA. Subsequently, cells were treated with increasing concentrations of DXM. Chondrocyte media were collected after $48 \mathrm{~h}$ (to ensure enough accumulation of protein to be measured) and centrifuged for $10 \mathrm{~min}$ at $3000 \mathrm{~g}\left(4^{\circ} \mathrm{C}\right)$ and stored at $-80^{\circ} \mathrm{C}$. The chondrocyte-conditioned medium $(1 \mathrm{ml})$ was concentrated 10-fold on Centricon-10 ultrafiltration membranes and loaded on a $12 \%$ gel for non-reducing
SDS-PAGE. IGFBPs were visualized by electrotransfer to PVDF membranes followed by incubation with ${ }^{125}$ I-IGF-II (ligand blotting) (Van Buul-Offers et al. 1994). Molecular masses were calculated using BioRad (Hercules, CA, USA) broad range markers as standard. Bands were quantified by densitometry using a GS-363 Molecular Imager and Molecular Analyst software program, version 1.5 (BioRad).

For immunoblotting, $10 \mathrm{ml}$ conditioned medium from $75 \mathrm{~cm}^{2}$ tissue culture flasks was concentrated 10 -fold on Centricon-10 ultrafiltration membranes. IGFBP-2 was detected using a bovine IGFBP-2 antibody at 1/2500 dilution, followed by a horseradish peroxidase-conjugated secondary antibody at $1 / 7500$ dilution. IGFBP-5 was detected using a human IGFBP-5 antibody at 1/2000 dilution, followed by a horseradish peroxidase-conjugated secondary antibody at 1/7500 dilution. The bands were visualized using the SuperSignal chemiluminescent substrate and Hyperfilm ECL film.

\section{Northern blot analysis}

RNA extraction Cells $\left(3 \times 10^{6}\right)$ were cultured in $75 \mathrm{~cm}^{2}$ tissue culture flasks and treated with DXM for $24 \mathrm{~h}$. Cells were directly lysed with Tripure solution reagent and total RNA was extracted according to the procedures of the manufacturer, based on the single-step acid guanidinium-thiocyanate method (Chomczynski \& Sacchi 1987).

Probes Twenty nanograms of gel-purified inserts of plasmids containing human IGFBP-1 to -6 , human IGF-I and -II, rat type I IGF receptor, mouse type II IGF receptor and rat GAPDH cDNA, were radiolabeled with $50 \mu \mathrm{Ci}$ $\left[\alpha_{-}{ }^{32} \mathrm{P}\right] \mathrm{dCTP}$, using random primed DNA labeling as described by the manufacturer.

Northern blot hybridization Twenty micrograms of total RNA were separated by electrophoresis in a $1 \%$ $(\mathrm{w} / \mathrm{v})$ agarose/2.2 $\mathrm{M}$ formaldehyde gel in $1 \times 3-$ (morpholino) propanesulfonic acid buffer, transferred to a $0 \cdot 2 \mu \mathrm{m}$ nylon membrane and crosslinked to the membrane by UV radiation.

The membranes were prehybridized for $2 \mathrm{~h}$ at $60{ }^{\circ} \mathrm{C}$ in a solution containing $0 \cdot 1 \%$ SDS, $3 \times$ SSC, $5 \times$ Denhardt's solution, $10 \%$ dextran sulfate and $50 \mu \mathrm{g} / \mathrm{ml}$ denaturated salmon sperm DNA. Hybridization was performed at $60{ }^{\circ} \mathrm{C}$ overnight in the same solution, containing the $\left[\alpha_{-}{ }^{32} \mathrm{P}\right] \mathrm{dCTP}-\mathrm{labeled}$ probe. Following hybridization, the membranes were washed to a stringency of $0 \cdot 2 \times$ SSC, $0 \cdot 1 \%(\mathrm{w} / \mathrm{v}) \mathrm{SDS}$ at $60{ }^{\circ} \mathrm{C}$. The hybridization signals were analyzed by densitometry using the GS-363 Molecular Imager and the Molecular Analyst software program (BioRad) and the relative abundance of the different mRNAs was subsequently normalized to the GAPDH 
A.

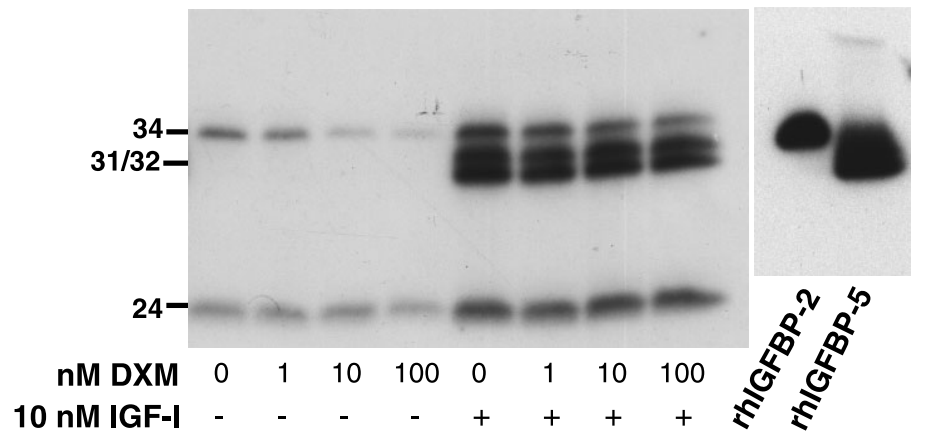

B.

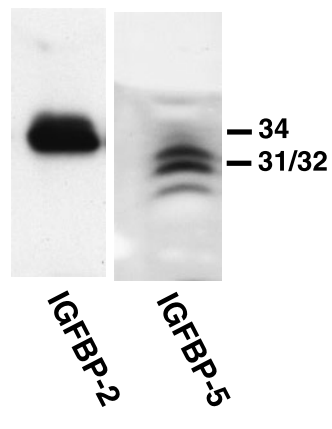

C.

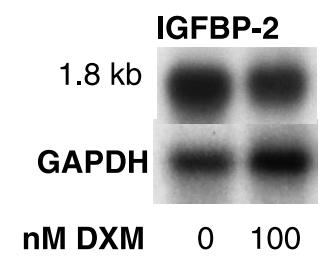

Figure 1 Characterization of secreted insulin-like growth factor-binding proteins (IGFBPs) and regulation by dexamethasone (DXM). (A) Growth plate chondrocytes were treated with increasing concentrations of DXM in serum-free medium in the absence ( -$)$ or presence $(+)$ of 10 nM IGF-I. Conditioned media were collected, concentrated and IGFBPs were detected by Western ligand blot analysis using

${ }^{125}$ I-IGF-II as described in Materials and Methods. Numbers on the left and right are molecular masses (in kDa) of the detected IGFBPs. (B) Identification of the major IGFBP species produced by the porcine growth plate chondrocytes. Recombinant human (rh) IGFBP-2 and IGFBP-5 were used as positive controls, as indicated, and detected using Western ligand blot analysis. IGFBPs in the conditioned media of chondrocytes were detected using immunoblotting using an anti-IGFBP-2 and anti-IGFBP-5 antibody, as indicated.

(C) Expression of IGFBP-2 mRNA in chondrocytes in IGF-I-supplemented serum-free medium in the absence and presence of DXM (100 nM). Total RNA was isolated and subjected to Northern blot analysis (as described in Materials and Methods). Subsequently, hybridization with a GAPDH probe was performed, which served as an internal control.

values. The signals were also visualized by autoradiography on BioMax MR X-ray films.

\section{GR RT-PCR}

Total RNA was isolated as described above. First strand cDNA synthesis of $3.5 \mu \mathrm{g}$ total RNA was performed using SuperScript II reverse transcriptase, as described by the manufacturer. After cDNA synthesis, the final volume was diluted to $100 \mu \mathrm{l}$. PCR amplification of the GR and GAPDH was performed using $5 \mu l$ template and $10 \mathrm{pmol}$ forward and reverse primers. The following primer pair was used for the GR: forward primer, 5'-GTGAGTACC TCTGGAGGACA-3'; reverse primer, 5'-CTTTGCCC ATTTCACTGC-3', which were expected to yield a $761 \mathrm{bp}$ product. Following an initial denaturation step of 5 min at $94^{\circ} \mathrm{C}$, amplification consisted of 34 cycles of $30 \mathrm{~s}$ at $92{ }^{\circ} \mathrm{C}, 45 \mathrm{~s}$ at $50^{\circ} \mathrm{C}, 60 \mathrm{~s}$ at $72{ }^{\circ} \mathrm{C}$, followed by a final extension step of $10 \mathrm{~min}$ at $72{ }^{\circ} \mathrm{C}$. The following primer pair was used for GAPDH: forward primer, $5^{\prime}$-CTCAA GATTGTCAGCAATGC-3'; reverse primer, 5'-TTGC CCACAGCCTTGGCA-3', which were expected to yield a $226 \mathrm{bp}$ product. Following an initial denaturation step of 5 min $94^{\circ} \mathrm{C}$, amplification consisted of 31 cycles of $30 \mathrm{~s}$ at $92{ }^{\circ} \mathrm{C}, 30 \mathrm{~s}$ at $53{ }^{\circ} \mathrm{C}, 60 \mathrm{~s}$ at $72{ }^{\circ} \mathrm{C}$, followed by a final extension step of $10 \mathrm{~min}$ at $72{ }^{\circ} \mathrm{C}$. PCR products were analyzed on a $1 \%$ agarose gel. Initial experiments established that the PCR reactions were in the log phase, allowing semi-quantitative determination of the mRNA levels. Densities of the bands were measured using digitized images coupled to the Molecular Analyst software and normalized for GAPDH expression.

\section{Statistical analysis}

Data are expressed as means \pm S.E.M. Statistical differences between two groups were determined by Student's $t$-test. Statistical differences between multiple treatments were determined by one-way ANOVA using InStat version 3.00 (GraphPad Software, Inc., San Diego, CA, USA). The Dunnett post-hoc test was used to determine significance between the control and the treatment groups. Significance of the difference between the various treatments with or without the GR antagonist in the $\left[{ }^{3} \mathrm{H}\right]$ thymidine incorporation were determined using the Bonferroni post-hoc test. A $P$ value of less than 0.05 was considered statistically significant. Growth plate cultures of at least three different animals were used per analyzed mRNA (both for the Northern Blot analysis and for the semi-quantitative RT-PCR) and for the $\left[{ }^{3} \mathrm{H}\right]$ thymidine incorporation.

\section{Results}

Characterization of secreted IGFBPs and regulation by DXM

The production of IGFBPs by the primary porcine growth plate chondrocytes was determined using Western ligand blot analysis. Under serum-free incubations, two IGFBPs of 34 and $24 \mathrm{kDa}$ were detected (Fig. 1A). When the medium was supplemented with $10 \mathrm{nM}$ IGF-I the expression of a $31 / 32 \mathrm{kDa}$ doublet was induced and the expression of the $24 \mathrm{kDa}$ protein was increased $2 \cdot 9$-fold (Fig. 1A). At $100 \mathrm{nM}$ DXM, the intensity of the $34 \mathrm{kDa}$ IGFBP, in both the absence and presence of IGF-I, was 
decreased to respectively 35 and $50 \%$ of control levels. The $24 \mathrm{kDa}$ band and the $31 / 32 \mathrm{kDa}$ doublet were not influenced by DXM treatment in either of the two incubations (Fig. 1A).

Immunoblotting identified the $34 \mathrm{kDa}$ band as IGFBP-2 (Fig. 1B) and the $31 / 32 \mathrm{kDa}$ doublet as IGFBP-5 (Fig. 1B). The band of $24 \mathrm{kDa}$ probably represents IGFBP-4 (Koedam et al. 2000). Therefore, the DXM-sensitive protein was identified as IGFBP-2 and the major IGF-I-inducible IGFBP produced by growth plate chondrocytes was identified as IGFBP-5. IGFBP-4 was increased by IGF-I, but not affected by the DXM treatment.

Northern blot analysis confirmed the expression of IGFBP-2, -4 and -5 at the mRNA level, when cultured in IGF-I-supplemented medium. In agreement with the protein levels, mRNA levels of IGFBP-2 $(1.8 \mathrm{~kb}$ transcript) were also decreased by DXM treatment to $69 \%$ of control values (Fig. 1C). IGFBP-4 and -5 mRNA levels were not affected by the DXM treatment (data not shown), in concert with the protein levels.

\section{DXM-induced growth retardation}

To determine the effect of DXM on chondrocyte proliferation, $\left[{ }^{3} \mathrm{H}\right]$ thymidine incorporation into DNA was measured. The $\left[{ }^{3} \mathrm{H}\right]$ thymidine incorporation decreased significantly to $66 \pm 3 \%$ of the control values when the chondrocytes were cultured in IGF-I-supplemented medium and subsequently treated with $100 \mathrm{nM}$ DXM (Fig. 2). However, when growth plate chondrocytes were cultured in the presence of $10 \%$ FCS, basal proliferation (without any further treatment) increased 3.5-fold when compared with chondrocytes cultured in IGF-Isupplemented medium. Subsequent treatment with $100 \mathrm{nM}$ DXM resulted in a $2 \cdot 0 \pm 0 \cdot 1$-fold reduction in proliferation (Fig. 2). Culturing in 10\% FCS, therefore, resulted in higher cell proliferation and a larger decrease in proliferation when treated with DXM.

Further experiments were conducted in the presence of $10 \% \mathrm{FCS}$, as this was shown to be the optimal condition to study GC-induced growth retardation. A doseresponse study showed that a significant decrease in the $\left[{ }^{3} \mathrm{H}\right]$ thymidine incorporation was observed at $50 \mathrm{nM}$ and higher concentrations of DXM (Fig. 3). The $\left[{ }^{3} \mathrm{H}\right]$ thymidine incorporation decreased to $37 \pm 4 \%$ of the control values at $100 \mathrm{nM}$ DXM and remained at 40-60\% of control values at higher doses. The trypan blue exclusion technique showed that the viability of the cells was the same at the different concentrations used, indicating that the decrease in $\left[{ }^{3} \mathrm{H}\right]$ thymidine incorporation was due to a decrease in proliferation.

Treatment with DXM in combination with the GR antagonist Org34116 abolished the DXM-induced growth inhibition, as shown in Fig. 3. The GR antagonist on its

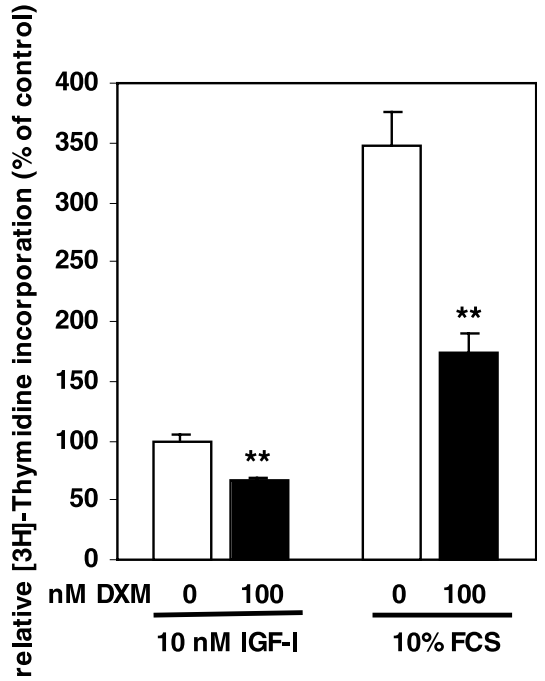

Figure 2 Modulation of $\left[{ }^{3} \mathrm{H}\right]$ thymidine incorporation into growth plate chondrocytes by DXM. Epiphyseal growth plate chondrocytes of neonatal piglets were cultured in 10\% FCSsupplemented medium. Treatment with $100 \mathrm{nM}$ DXM was for $24 \mathrm{~h}$ in $10 \% \mathrm{FCS}$ or in serum-free medium in the presence of $10 \mathrm{nM}$ IGF-I, as indicated. For the final $4 \mathrm{~h},\left[{ }^{3} \mathrm{H}\right]$ thymidine was added and the incorporation assessed as described in Materials and Methods. For the DXM-treated chondrocytes (shaded bars), means \pm S.E.M. are expressed relative to incorporation levels of untreated chondrocytes (open bars), ${ }^{* *} P<0 \cdot 01$. The Figure shows the results of a typical experiment performed in triplicate. The experiment was performed another three times with different chondrocyte cultures, derived from three different piglets, each giving similar results.

own resulted in a small, but not significant, decrease in proliferation as compared with control values.

To exclude the possibility that the GR was downregulated by the treatment with DXM, we also performed RT-PCR of the GR on RNA extracted from our primary chondrocytes and found the expected $761 \mathrm{bp}$ product, indicating that these chondrocytes expressed the GR (Fig. 4). Increasing concentrations of DXM did not affect the mRNA levels of the GR as shown by semiquantitative RT-PCR analysis. Although a decrease in mRNA levels at $500 \mathrm{nM}$ DXM $(74 \pm 14 \%$ of control values; $n=5)$ was visible, this was not statistically significant (Fig. 4).

$m R N A$ levels of IGF axis components and regulation by DXM

Northern blot analysis of primary porcine growth plate chondrocytes cultured in 10\% FCS showed expression of the same IGFBP species as detected at the protein level (Fig. 1). The major transcripts detected (Fig. 5A) were: IGFBP-2 $(1 \cdot 8 \mathrm{~kb})$, IGFBP-4 $(2 \cdot 0 \mathrm{~kb})$ and IGFBP-5 $(7 \cdot 0 \mathrm{~kb})$. IGFBP-6 mRNA was detected at low levels $(2 \cdot 0 \mathrm{~kb})$. No IGFBP-1 and only very weak IGFBP-3 


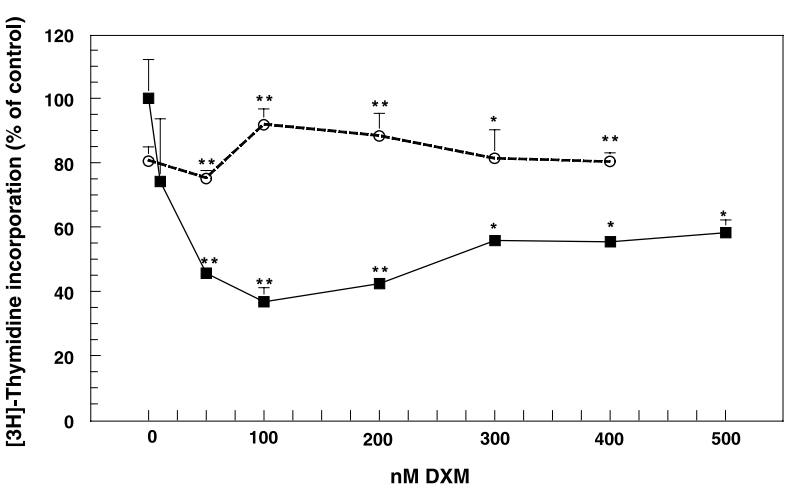

Figure 3 Modulation of $\left[{ }^{3} \mathrm{H}\right]$ thymidine incorporation into growth plate chondrocytes cultured in 10\% FCS-supplemented medium and subsequent treatment with increasing concentrations of DXM for $24 \mathrm{~h} \mathrm{( \square )}$ and with DXM in combination with the glucocorticoid receptor (GR) antagonist $(\bigcirc)$. $\left[{ }^{3} \mathrm{H}\right]$ thymidine incorporation was assessed as described in Fig. 2. For the DXM-treated chondrocytes, means \pm S.E.M. are expressed relative to incorporation levels of untreated chondrocytes (0 nM DXM), ${ }^{*} P<0 \cdot 05,{ }^{* *} P<0 \cdot 01$. For the co-incubation with the GR antagonist, means \pm S.E.M. are expressed relative to incorporation levels of the corresponding DXM-treated chondrocytes treated with the same dose of DXM, ${ }^{*} P<0 \cdot 05,{ }^{*} P<0 \cdot 01$. The Figure shows the results of a typical experiment performed in triplicate. The experiment was performed another four times with different chondrocyte cultures, derived from four different piglets, each giving similar results.

expression $(5.0 \mathrm{~kb}$, in one out of five conducted experiments) was found (not shown).

We determined the effects of pharmacological doses of DXM on the expression of IGF axis components in growth plate chondrocytes cultured in 10\% FCS using Northern blot analysis. The IGFBP-2 mRNA levels decreased to $45 \pm 9 \%$ of the control values, when treated with $100 \mathrm{nM}$ DXM (Fig. 5A). The $7 \cdot 0 \mathrm{~kb}$ transcript of IGFBP-5 was significantly increased by $2 \cdot 0 \pm 0 \cdot 2$-fold at $100 \mathrm{nM}$ DXM (Fig. 5A). The mRNA levels of IGFBP-4 and -6 were not affected by the DXM treatment (Fig. 5A). The levels of IGFBP-3 were too low to be quantified.

Besides the IGFBPs, we also studied the presence and effects of DXM treatment on the remaining IGF axis components. The growth plate chondrocytes of neonatal piglets expressed very low levels of a $5.0 \mathrm{~kb}$ IGF-I transcript (data not shown). Northern blots hybridized with a ${ }^{32} \mathrm{P}-$ labeled human IGF-II cDNA probe revealed

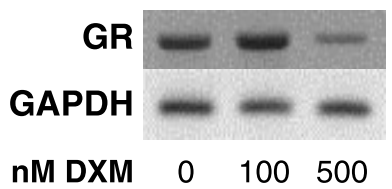

Figure 4 Expression of the GR. Cells were treated with the indicated concentrations of DXM for $24 \mathrm{~h}$ and total RNA was isolated as described in Materials and Methods and analyzed using semi-quantitative RT-PCR analysis. GAPDH served as an internal control. The Figure shows the results of a typical experiment. four transcripts of IGF-II of $4 \cdot 6,2 \cdot 6,1 \cdot 8$ and $1.5 \mathrm{~kb}$ respectively (Fig. 5B). Low levels of a transcript of $11 \mathrm{~kb}$ of the type I IGF receptor were detected (Fig. 5B), and low levels of a transcript of $9 \cdot 0 \mathrm{~kb}$ of the type II IGF receptor (mannose-6-phosphate receptor) (Fig. 5B).

DXM treatment did not affect the expression levels of the four detected transcripts of IGF-II (Fig. 5B). Also, the mRNA levels of the type II IGF receptor were not affected (Fig. 5B). The levels of IGF-I were too low to be quantified. In contrast, type I IGF receptor expression levels increased when treated with $100 \mathrm{nM}$ DXM (approximately 2- to 3-fold) (Fig. 5B); due to the low expression level of the untreated chondrocytes, no precise quantification of the increase was possible.

Treatment with DXM in combination with the GR antagonist (Org34116) abolished the effects of DXM on the mRNA levels of IGFBP-2 and -5 , as shown in Fig. 5A. Similarly, the GR antagonist prevented the DXM-induced increase of mRNA levels of the type I IGF receptor, although quantification was not possible due to the low expression levels as described in Fig. 5B (data not shown).

\section{Discussion}

This is the first study to describe the possible involvement of all the IGF axis components, the IGFs, both IGF receptors and the IGFBPs, in GC-induced growth retardation at the local level of the growth plate chondrocytes. Epiphyseal tibial growth plate chondrocytes of neonatal piglets were used as a model system for postnatal growth. The chondrocytes were treated with high (pharmacological) doses of DXM to induce growth retardation and levels of the IGF axis components were determined at the protein and mRNA level.

First, we characterized the production and regulation of the IGFBPs by the primary porcine growth plate chondrocytes as the IGFBPs could be the IGF axis components that are involved in GC-induced growth retardation (Unterman \& Phillips 1985, Price et al. 1992). We have previously reported that IGFBP-5 is the major IGF-Iinducible IGFBP produced by rabbit costal chondrocytes (Koedam et al. 2000). The present result in porcine epiphyseal growth plate chondrocytes confirmed this finding. In contrast to the costal chondrocytes, the growth plate chondrocytes expressed IGFBP-2, and showed upregulation of IGFBP-4 by IGF-I. Further differences are noted with respect to the regulation by DXM. While DXM inhibited the expression of IGFBP-5 in the costal chondrocytes (Koedam et al. 2000), this binding protein was unaffected by DXM at the protein level. In addition, we reported an induction of IGFBP-3 in the costal chondrocytes, while IGFBP-3 remained undetected in the growth plate chondrocytes in the presence of DXM. As costal chondrocytes of the neonatal piglets showed similar 
A.
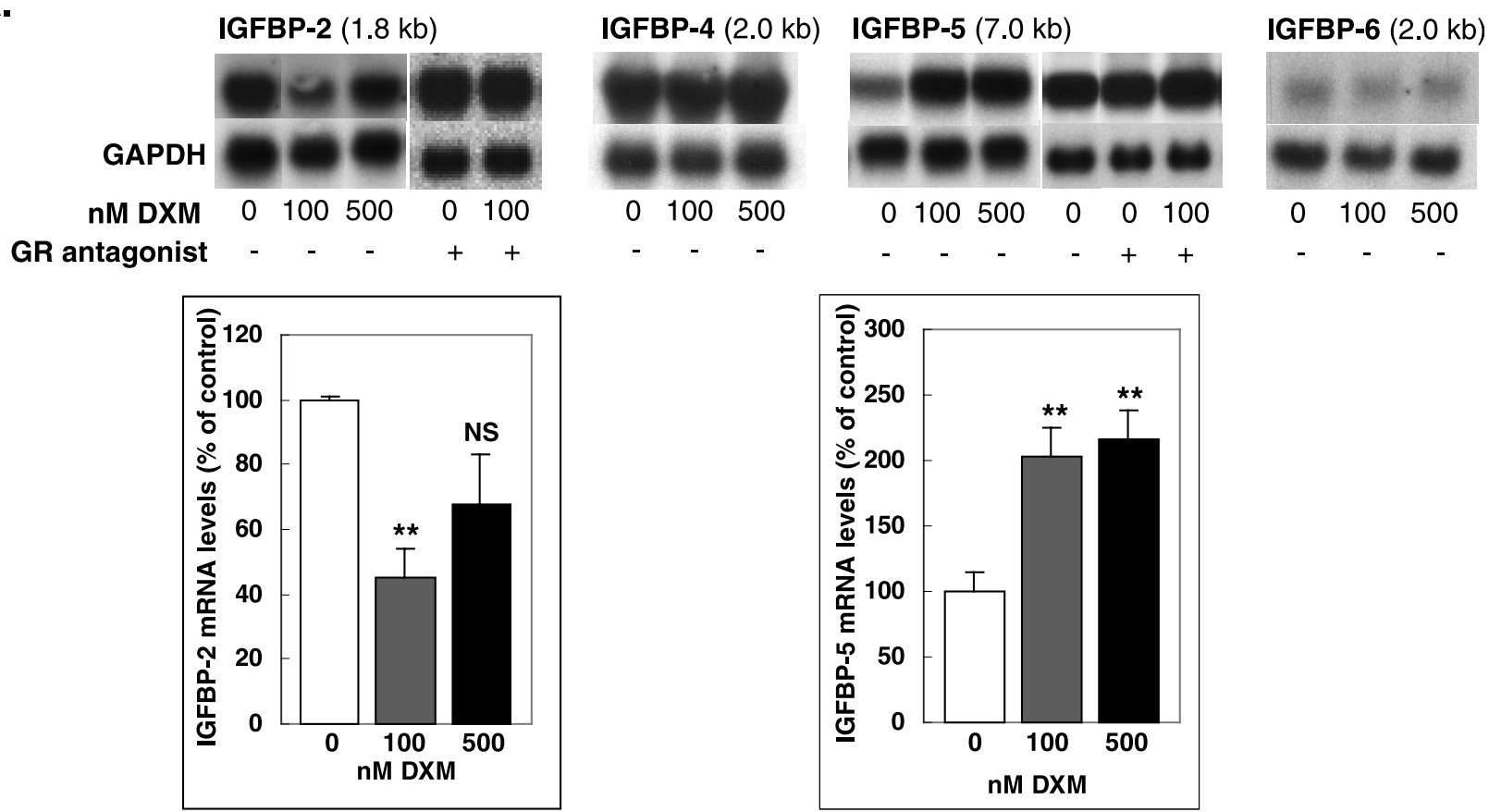

B.

\section{IGF-II}

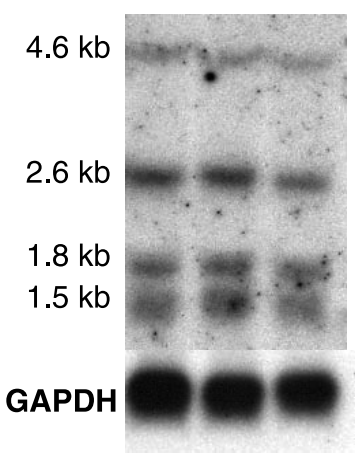

Type I IGF receptor

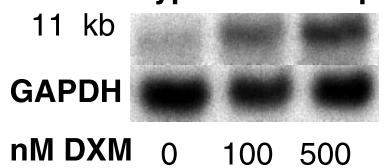

Type II IGF receptor

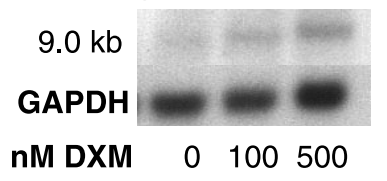

nM DXM $0 \quad 100 \quad 500$

Figure 5 Expression of IGF axis components in porcine growth plate chondrocytes cultured in 10\% FCS-supplemented medium and effects of DXM treatment. Growth plate chondrocytes were treated with DXM (100 and $500 \mathrm{nM}$ ) (as indicated) for $24 \mathrm{~h}$ and analyzed as described in Fig. 1C. (A) mRNAs of IGFBP-2, $-4,-5$ and -6 (as indicated). The data are expressed relative to mRNA levels of control values (open bars). mRNA levels of IGF axis components affected by DXM treatment were also co-incubated with the GR antagonist (Org34116), as indicated (+). (B) mRNA levels of IGF-II and the type I and II IGF receptor (as indicated). The relative abundance of the different mRNAs was quantified by densitometry (as described in Materials and Methods) and normalized to the GAPDH values. The data represent the means \pm S.E.M. of at least four different animals per analyzed transcript, the means \pm S.E.M. are expressed relative to expression levels of untreated chondrocytes, ${ }^{* *} P<0 \cdot 01$, NS, non significant. Representative Northern blot data are shown.

results to the porcine tibial growth plate chondrocytes (data not shown), we suggest that species and/or age differences can account for these differences and not the difference in the origin of the tissue of the chondrocytes. The decrease in IGFBP-2 protein levels was paralleled by a decrease of IGFBP-2 mRNA levels, suggesting a regulation at the transcriptional level. GCs have indeed been shown to affect IGF axis components primarily at the level of gene expression (Price et al. 1992, Okazaki et al. 1994, Dell et al. 1999, Koedam et al. 2000).

GC treatment of our chondrocytes resulted in inhibition of proliferation without an increase in cell death, in 
accordance with other in vitro studies, e.g. in osteoblasts (Okazaki et al. 1994) and in tibial growth plate chondrocytes (Jux et al. 1998, Robson et al. 1998). It has been previously reported that the decreased proliferation of chondrocytes treated with GCs is due to an increase in cell doubling times with a reduction in the number of $\mathrm{S}$ phase cells; in addition, no signs of increasing cell death or increase in morphological signs of apoptosis were shown (Jux et al. 1998, Robson et al. 1998).

We found that basal proliferation in IGF-Isupplemented medium was much lower than proliferation in serum-supplemented medium. Subsequently, inhibition of proliferation due to GC treatment resulted in a larger decrease in proliferation. Therefore, further experiments to study GC-induced growth retardation were conducted in these conditions. In addition, treatment of the chondrocytes with a GR antagonist prevented the DXM-induced growth retardation, which provides evidence for both the specific effects of DXM on growth and the presence of an active GR.

As a consequence of the presence of serum in the experimental conditions, measurements of IGFBP protein production by the porcine tibial growth plate chondrocytes were unreliable. Further study of the effects of DXM on the IGF axis components (including also both IGFs and IGF receptors) on the growth plate chondrocytes was therefore only performed at the mRNA level. Northern blot analysis showed that not all components of the IGF axis were expressed in neonatal porcine growth plate chondrocytes. IGFBP-1 was not detected, as described previously (de los Rios \& Hill 1999), and only very low levels of IGFBP-3 and low levels of IGFBP-6 were shown. IGFBP-2, -4 and -5 were the predominant IGFBPs expressed by the growth plate chondrocytes, which was in accord with the IGFBPs detected at the protein level in IGF-I-supplemented serum-free culture conditions. This is in accordance with data from others, who also showed expression of IGFBP-2 to -6 in growth plate chondrocytes (Olney \& Mougey 1999, de los Rios \& Hill 1999). In accordance with others, we found IGF-II to be the most prominent IGF expressed in the growth plate (Shinar et al. 1993). Only very low levels of IGF-I were detected. Expression of the type I IGF receptor was also previously observed in rat growth plate chondrocytes (Klaus et al. 2000). This is the first study to describe expression of the type II IGF receptor in growth plate chondrocytes.

Pharmacological doses of DXM did not influence the expression of IGFBP-3, -4 and -6 , of both IGFs and of the type II IGF receptor. This contrasts with the observed effects of GCs on other cell types as downregulation by GCs of the type II IGF receptor (Rydziel \& Canalis 1995) and IGFBP-4 (Okazaki et al. 1994) in osteoblasts. IGFBP-6 was shown both to be stimulated in osteoblasts (Gabbitas \& Canalis 1996) and to be not affected by GCs in osteoblasts (Okazaki et al. 1994) and in fibroblasts (Conover et al. 1995). IGFBP-3 expression was stimulated by GCs in costal chondrocytes (Koedam et al. 2000). Obviously, the regulation of expression of IGF axis components is cell type specific, and also depends on developmental stage and species used (Dell et al. 1999).

DXM treatment did influence the expression levels of the type I IGF receptor, IGFBP-5 and IGFBP-2. We showed that pharmacological doses of DXM increased the type I IGF receptor mRNA levels in the growth plate chondrocytes. This increase of type I IGF receptor mRNA by DXM has previously been shown in vivo (Price et al. 1992) and might be a response to counteract the effect of the GC-induced growth retardation. However, this response is insufficient to compensate for the growth inhibition observed.

DXM treatment increased IGFBP-5 mRNA levels in the presence of $10 \%$ FCS, which has not been described previously. In contrast, reduction of IGFBP-5 levels was reported in costal chondrocytes (Koedam et al. 2000), osteoblasts (Okazaki et al. 1994, Gabbitas et al. 1996) and in fibroblasts (Conover et al. 1995), a discrepancy which is probably due to a difference in cell type and species used as discussed above (Dell et al. 1999). In the rabbit costal chondrocytes we described before (Koedam et al. 2000), a decrease in IGFBP-5 was shown due to DXM treatment, whereas an increase in IGFBP-3 was observed. In contrast, our porcine growth plate chondrocytes expressed almost no IGFBP-3, but expressed IGFBP-5 at a high level. It has been suggested that IGFBP-3 and IGFBP-5 could have similar functions (Booth et al. 1995, Schedlich et al. 1998, Twigg \& Baxter 1998). An increase in IGFBP-5 due to DXM treatment in piglet growth plate chondrocytes could therefore resemble the increase in IGFBP-3 due to DXM treatment in rabbit costal chondrocytes (Koedam et al. 2000). Furthermore, IGFBP-5 inhibits IGF-II-dependent DNA synthesis in growth plate chondrocytes (de los Rios \& Hill 1999). An increase in IGFBP-5 thus can inhibit proliferation of growth plate chondrocytes by inhibiting IGF-II activity, which is the predominant IGF in our growth plate chondrocytes. IGFBP-5 could therefore account in part for the GC-induced growth retardation observed in our growth plate chondrocytes.

We observed a decrease in IGFBP-2 due to DXM treatment, both in IGF-I-supplemented experimental conditions as well as in the presence of $10 \%$ FCS. This observation is in accordance with data on osteoblasts (Chen et al. 1991) and in vivo experiments (Orlowski et al. 1990). Treatment of chondrocytes with GH increased IGFBP-2 levels (Borromeo et al. 1996). Together with our data, this implies that IGFBP-2 levels are correlated with growth in chondrocytes. IGFBP-2 can inhibit, but also stimulate, IGF activity and it has a preference for binding IGF-II (Jones \& Clemmons 1995), the predominant IGF in the growth plate. IGFBP-2 was also suggested to facilitate targeting of the IGFs, in particular IGF-II prohormone, to skeletal tissues, resulting in stimulation of proliferation (Khosla et al. 1998). A decrease in IGFBP-2 
could result in a decrease in IGF targeted to the chondrocytes, resulting in a decreased proliferation. Downregulation of IGFBP-2 expression in chondrocytes might therefore contribute to the inhibition of growth. This strengthens our conclusion that IGFBP-2, the only IGFBP which is affected by DXM in different culture conditions, could play a role in the regulation of growth in the growth plate, the mechanisms of which needs to be further elucidated.

In conclusion, all the IGF axis components (besides IGFBP-1) are present in neonatal porcine chondrocytes and some specific components, such as the type I IGF receptor, IGFBP-2 and -5 , are regulated by GCs at the local level. These specific changes of IGF axis components by GCs indicate an impaired function of the IGF axis and might contribute to the GC-induced growth retardation.

\section{Acknowledgements}

We are grateful to Ms C M P C D Peeters and Dr F Groenendaal for providing the tibia of the neonatal piglets. Thanks are also due to $\mathrm{Mr} \mathrm{C} \mathrm{M}$ Hoogerbrugge for technical assistance.

\section{References}

Allen DB 1996 Growth suppression by glucocorticoid therapy. Endocrinology and Metabolism Clinics of North America 25 699-717.

Baron J, Huang Z, Oerter KE, Bacher JD \& Cutler GC 1992 Dexamethasone acts locally to inhibit longitudinal bone growth in rabbits. American Journal of Physiology 263 E489-E492.

Bhaumick B 1993 Insulin-like growth factor (IGF) binding proteins and insulin-like growth factor secretion by cultured chondrocyte cells: identification, characterization and ontogeny during cell differentiation. Regulatory Peptides 48 113-122.

Booth BA, Boes M, Andress DL, Dake BL, Kiefer MC, Maack C, Linhardt RJ, Bar K, Caldwell EE, Weiler J \& Bar RS 1995 IGFBP-3 and IGFBP-5 association with endothelial cells: role of C-terminal heparin binding domain. Growth Regulation 5 1-17.

Borromeo V, Bramani S, Holder AT, Carter C, Secchi C \& Beattie J 1996 Growth hormone stimulates the secretion of insulin-like growth factor binding protein-2 (IGFBP-2) by monolayer cultures of sheep costal growth plate chondrocytes. Molecular and Cellular Biochemistry 162 145-151.

Cancedda R, Descalzi CF \& Castagnola P 1995 Chondrocyte differentiation. International Review of Cytology 159 265-358.

Caufriez A \& Copinschi G 1986 Somatomedins and steroids. Hormone Research 24 185-188.

Chen TL, Chang LY, Bates RL \& Perlman AJ 1991 Dexamethasone and 1,25-dihydroxyvitamin $\mathrm{D}_{3}$ modulation of insulin-like growth factor-binding proteins in rat osteoblast-like cell cultures. Endocrinology 128 73-80.

Chomczynski P \& Sacchi N 1987 Single-step method of RNA isolation by acid guanidinium thiocyanate-phenol-chloroform extraction. Analytical Biochemistry 162 156-159.

Clemmons DR 1997 Insulin-like growth factor binding proteins and their role in controlling IGF actions. Cytokine and Growth Factor Reviews 8 45-62.

Cohick WS \& Clemmons DR 1993 The insulin-like growth factors. Annual Review of Physiology 55 131-153.
Conover CA, Clarkson JT \& Bale LK 1995 Effect of glucocorticoid on insulin-like growth factor (IGF) regulation of IGF-binding protein expression in fibroblasts. Endocrinology 136 1403-1410.

Dell G, Ward A, Shokrai A, Madej A \& Engstrom W 1999 Regulation of the IGF system by glucocorticoids. Zoological Science 16 377-385.

D'Ercole AJ 1996 Insulin-like growth factors and their receptors in growth. Endocrinology and Metabolism Clinics of North America 25 573-590.

Dietz UH \& Sandell LJ 1996 Cloning of a retinoic acid-sensitive mRNA expressed in cartilage and during chondrogenesis. Journal of Biological Chemistry 271 3311-3316.

Dufourny B, Alblas J, Van Teeffelen HAAM, Van Schaik FMA, van der Burg B, Steenbergh PH \& Sussenbach JS 1997 Mitogenic signalling of insulin-like growth factor I in MCF-7 human breast cancer cells requires phophatidylinositol 3-kinase and is independent of mitogen-activated protein kinase. Journal of Biological Chemistry 272 31163-31171.

Gabbitas B \& Canalis E 1996 Cortisol enhances the transcription of insulin-like growth factor-binding protein-6 in cultured osteoblasts. Endocrinology 137 1687-1692.

Gabbitas B, Pash JM, Delany AM \& Canalis E 1996 Cortisol inhibits the synthesis of insulin-like growth factor-binding protein-5 in bone cell cultures by transcriptional mechanisms. Journal of Biological Chemistry 271 9033-9038.

Han VK, Matsell DG, Delhanty PJ, Hill DJ, Shimasaki S \& Nygard K 1996 IGF-binding protein mRNAs in the human fetus: tissue and cellular distribution of developmental expression. Hormone Research 45 160-166.

Jansen M, Van Schaik FMA, Ricker AT, Bullock B, Woods DE, Gabbay KH, Nussbaum AL, Sussenbach JS \& Van den Brande JL 1983 Sequence of cDNA encoding human insulin-like growth factor I precursor. Nature 306 609-611.

Jansen M, Van Schaik FMA, Van Tol H, Van den Brande JL \& Sussenbach JS 1985 Nucleotide sequences of cDNAs encoding precursors of human insulin-like growth factor II (IGF-II) and an IGF-II variant. FEBS Letters 179 243-246.

Jones JI \& Clemmons DR 1995 Insulin-like growth factors and their binding proteins: biological actions. Endocrine Reviews 16 3-34.

Jux C, Leiber K, Hugel U, Blum W, Ohlsson C, Klaus G \& Mehls O 1998 Dexamethasone impairs growth hormone (GH)-stimulated growth by suppression of local insulin-like growth factor (IGF)-I production and expression of GH- and IGF-I-receptor in cultured rat chondrocytes. Endocrinology 139 3296-3305.

Khosla S, Hassoun AAK, Baker BK, Liu F, Zein NN, Whyte MP, Reasner CA, Nippoldt TB, Tiegs RD, Hintz RL \& Conover CA 1998 Insulin-like growth factor system abnormalities in hepatitis C-associated osteosclerosis. Journal of Clinical Investigation 101 2165-2173.

Klaus G, Weber L, Rodriguez J, Fernandez P, Klein T, Grulich HJ, Hugel U, Ritz E \& Mehls P 1998 Interaction of IGF-I and 1 alpha, $25(\mathrm{OH}) 2 \mathrm{D} 3$ on receptor expression and growth stimulation in rat growth plate chondrocytes. Kidney International $\mathbf{5 3}$ 1152-1161.

Klaus G, Jux C, Fernandez P, Rodriguez J, Himmele R \& Mehls O 2000 Suppression of growth plate chondrocyte proliferation by corticosteroids. Pediatric Nephrology 14 612-615.

Koedam JA, Hoogerbrugge CM \& Van Buul-Offers SC 2000 Differential regulation of IGF-binding proteins in rabbit costal chondrocytes by IGF-I and dexamethasone. Journal of Endocrinology 165 557-567.

Koedam JA, Smink JJ \& Van Buul-Offers SC 2002 Glucocorticoids inhibit vascular endothelial growth factor expression in growth plate chondrocytes. Molecular and Cellular Endocrinology (In Press).

Leili S \& Scanes CG 1998 The effects of glucocorticoids (dexamethasone) on insulin-like growth factor-I, IGF-binding proteins, and growth in chickens. Proceedings of the Society for Experimental Biology and Medicine 218 329-333. 
Leonard C, Fuld HM, Frenz DA, Downie SA, Massague J \& Newman SA 1991 Role of transforming growth factor beta in chondrogenic pattern formation in the embryonic limb. Developmental Biology 145 99-109.

Ludwig T, Ruther U, Metzger R, Copeland NG, Jenkins NA, Lobel P \& Hoflack B 1992 Gene and pseudogene of the mouse cationdependent mannose 6-phosphate receptor. Journal of Biological Chemistry 267 12211-12219.

Miell JP, Taylor AM, Jones J, Holly JMP, Gaillard RC, Pralong FP, Ross RJM \& Blum WF 1993 The effects of dexamethasone treatment on immunoreactive and bioactive insulin-like growth factors (IGFs) and IGF-binding proteins in normal male volunteers. Journal of Endocrinology 136 525-533.

Ohlsson C, Bengtsson BA, Isaksson OG, Andreassen TT \& Slootweg MC 1998 Growth hormone and bone. Endocrine Reviews 19 55-79.

Okazaki R, Riggs BL \& Conover CA 1994 Glucocorticoid regulation of insulin-like growth factor-binding protein expression in normal human osteoblast-like cells. Endocrinology 134 126-132.

Olney RC \& Mougey EB 1999 Expression of the components of the insulin-like growth factor axis across the growth plate. Molecular and Cellular Endocrinology 156 67-71.

Orlowski CC, Brown AL, Ooi GT, Yang YW, Tseng LY \& Rechler MM 1990 Tissue, developmental, and metabolic regulation of messenger ribonucleic acid encoding a rat insulin-like growth factor-binding protein. Endocrinology 126 644-652.

Price WA, Stiles AD, Moats-Staats BM \& D’Ercole AJ 1992 Gene expression of insulin-like growth factors (IGFs), the type 1 IGF receptor, and IGF-binding proteins in dexamethasone-induced fetal growth retardation. Endocrinology 130 1424-1432.

Rajaram S, Baylink DJ \& Mohan S 1997 Insulin-like growth factorbinding proteins in serum and other biological fluids: regulation and functions. Endocrine Reviews 18 801-831.

de los Rios P \& Hill DJ 1999 Cellular localization and expression of insulin-like growth factors (IGFs) and IGF binding proteins within the epiphyseal growth plate of the ovine fetus: possible functional implications. Canadian Journal of Physiology and Pharmacology 77 235-249.

Robson H, Anderson E, Eden OB, Isaksson O \& Shalet S 1998 Chemotherapeutic agents used in the treatment of childhood malignancies have direct effects on growth plate chondrocyte proliferation. Journal of Endocrinology 157 225-235.

Rooman R, Koster JG, Bloemen RJ, Gresnigt R \& Van Buul-Offers SC 1999 The effect of dexamethasone on body and organ growth of normal and IGF-II transgenic mice. Journal of Endocrinology 163 543-552.

Rydziel S \& Canalis E 1995 Cortisol represses IGF II receptor transcription in skeletal cell cultures. Endocrinology 136 4254-4260.
Schedlich LJ, Young TF, Firth SM \& Baxter RC 1998 Insulin-like growth factor-binding protein (IGFBP)-3 and IGFBP-5 share a common nuclear transport pathway in T47D human breast carcinoma cells. Journal of Biological Chemistry 273 18347-18352.

Shinar DM, Endo N, Halperin D, Rodan GA \& Weinreb M 1993 Differential expression of insulin-like growth factor-I (IGF-I) and IGF-II messenger ribonucleic acid in growing rat bone.

Endocrinology 132 1158-1167.

Silvestrini G, Ballanti P, Patacchioli FR, Mocetti P, Di Grezia R, Martin Wedard B, Angelucci L \& Bonucci E 2000 Evaluation of apoptosis and the glucocorticoid receptor in the cartilage growth plate and metaphyseal bone cells of rats after high-dose treatment with corticosterone. Bone 26 33-42.

Stevens DA \& Williams GR 1999 Hormone regulation of chondrocyte differentiation and endochondral bone formation. Molecular and Cellular Endocrinology 151 195-204.

Sunic D, Belford DA, McNeil JD \& Wiebkin OW 1995 Insulin-like growth factor binding proteins (IGF-BPs) in bovine articular and ovine growth-plate chondrocyte cultures: their regulation by IGFs and modulation of proteoglycan synthesis. Biochimica et Biophysica Acta 1245 43-48.

Twigg SM \& Baxter RC 1998 Insulin-like growth factor (IGF)-binding protein 5 forms an alternative ternary complex with IGFs and the acid-labile subunit. Journal of Biological Chemistry 273 6074-6079.

Unterman TG \& Phillips LS 1985 Glucocorticoid effect on somatomedins and somatomedin inhibitors. Journal of Clinical Endocrinology and Metabolism 61 618-626.

Van Buul-Offers SC, Hoogerbrugge CM, Branger J, Feijlbrief M \& Van den Brande JL 1988 Growth-stimulating effects of somatomedin-/insulin-like peptides in Snell dwarf mice. Hormone Research 29 229-236.

Van Buul-Offers SC, Reijnen-Gresnigt MG, Hoogerbrugge CM, Blomen RJ, Kuper CF \& Van den Brande JL 1994 Recombinant insulin-like growth factor-II inhibits the growth-stimulating effect of growth hormone on the liver of Snell dwarf mice. Endocrinology 135 977-985.

Ward WE, Atkinson SA, Donovan SM \& Paes B 1999 Bone metabolism and circulating IGF-I and IGFBPs in dexamethasonetreated preterm infants. Early Human Development 56 127-141.

Werner H, Woloschak M, Adamo M, Shen-Orr Z, Roberts CT Jr \& LeRoith D 1989 Developmental regulation of the rat insulin-like growth factor I receptor gene. PNAS 86 7451-7455.

Received 5 February 2002

Accepted 23 April 2002 